\title{
Morteros de escoria activada alcalinamente reforzados con fibra de vidrio AR. Comportamiento y propiedades
}

\author{
Alkali-activated slag mortars reinforced with ar glassfibre. \\ Performance and properties
}

\author{
F. Puertas $^{(*)}$, A. Gil-Maroto(*), M. Palacios(*), T. Amat ${ }^{(*)}$
}

Recepción/Received: 1-X-05

Aceptación/Accepted: 1-II-06

\begin{abstract}
RESUMEN
El principal problema tecnológico de los cementos de esconia activada alcalinamente (AAS) es su elevada retracción al secado. Por ello, en el presente trabajo se estudia el comportamiento de morteros de escoria activada alcalinamente reforzados con fibras de vidrio alcali-resistentes (AR), especialmente diseñadas para reducir la retracción al secado en sistema cementantes. Para ello se prepararon morteros de escoria activada alcalinamente y de cemento Portland como material de referencia. El porcentaje de fibra AR en los morteros varió entre $0-1,1 \%$ en peso de ligante. Los morteros preparados fueron sometidos a los siguientes ensayos: retracción al secado, resistencias mecánicas a 2, 7 y 28 días, ensayos de tenacidad, resistencia al impacto y comportamiento resistente frente a altas temperaturas. También se realizó un examen microestructural de los materiales a través de SEM/EDX. Se concluye que el porcentaje de $0,22 \%$ de fibra induce una reducción significativa (más de un $20 \%$ ) en la retracción al secado de los morteros de escoria activada, sin que se produzcan modificaciones negativas en el comportamiento resistente. Los morteros de escoria activada alcalinamente recuperan el $20 \%$ de sus resistencias mecánicas iniciales, mientras que dicha recuperación es del $50 \%$ cuando se incorpora un $0,22 \%$ de fibras de vidrio.
\end{abstract}

Palabras clave: morteros de escoria activada, fibra de vidrio, resistencias mecánicas, retracción, comportamiento frente a altas temperaturas.

\section{SUMMARY}

In light of the practical problem posed by the high drying shrinkage rate exhibited by alkali-activated slag (AAS), due to these materials exhibited a high drying shrinkage the present study analyzes the behaviour of alkali-activated slag mortars reinforced with alkali-resistant (AR) glassfibre especially designed to reduce drying shrinkage in cementitious systems. To this end, both alkali-activated slag and reference Portland cement mortars were prepared, with and without $A R$ fibre (in dosages ranging from 0 to $1.1 \%$ by weight of the binder). These mortars were subjected to the following tests: drying shrinkage, mechanical strength after 2, 7 and 28 days, toughness, and high temperature. The microstructure of the materials was also studied by SEM/EDX techniques. At a percentage of $0.22 \%$, AR fibre was found to induce a significant reduction (over 20\%) in drying shrinkage, without detracting from the fine resistance strength, of alkaliactivated slag mortar. Moreover, plain activated slag mortars recovered $20 \%$ of their initial mechanical strength after exposure to high temperatures, and in specimens reinforced with glassfibre at a rate of $0.22 \%$, recovery climbed to $50 \%$.

Keywords: alkali-activated slag mortars, glassfibre, mechanical strength, shrinkage, heat resistance.

(*) Instituto de Ciencias de la Construcción Eduardo Torroja (CSIC), Madrid (España).

Persona de contacto/Corresponding author: puertasf@ietcc.csic.es (F. Puertas). 


\section{INTRODUCCIÓN}

La fabricación de cemento Portland es un proceso energéticamente costoso (se invierten cerca de $7.000 \mathrm{Mj} / \mathrm{t}$ de cemento) y altamente contaminante (se estima que por cada tonelada de cemento se emite una tonelada de $\mathrm{CO}_{2}$ ). La necesidad de alcanzar la sostenibilidad en el proceso de obtención del cemento Portland implica la búsqueda de mejora de los procesos actuales (implementación de mejoras tecnológicas y valorización de residuos como sustitutos parciales de los combustibles y materias primas) y el desarrollo de nuevos conglomerantes de elevada eficiencia energética y baja contaminación. Entre éstos se encuentran los denominados "cementos y hormigones alcalinos", los cuales se obtienen por la mezcla íntima de una disolución fuertemente alcalina y una material, que puede ser de origen natural (arcillas) o artificial (escorias de horno alto o cenizas volantes silicoaluminosas). Las características y propiedades de estos cementos varían mucho dependiendo del material de partida.

Cuando el material de partida es la escoria vítrea de horno alto, se obtienen los cementos alcalinos denominados de escorias activadas alcalinamente. Estos cementos fueron desarrollados inicialmente por V. D. Glukhoswskii (1-2) en la década de los años 60, pero fue a partir de los años 90 cuando estos cementos fueron objeto de interés y estudio por parte de la comunidad científica internacional.

Los cementos y hormigones de escorias activadas alcalinamente se caracterizan por desarrollar unas resistencias comparables a las del cemento Portland, pudiendo alcanzar resistencias a la compresión de 30-40 MPa a las 24 horas. Diferentes autores han comprobado la elevada resistencia química de estos cementos y hormigones frente al ataque por sulfatos y al agua de mar (3-4), a la difusión de cloruros (5), a los medios ácidos (6), a ciclos hielo-deshielo (7-8), a altas temperaturas (9), etc. Este óptimo comportamiento durable está asociado a la naturaleza de los productos de hidratación (10-11), y a la baja porosidad y permeabilidad de estos hormigones (12). Sin embargo, los cementos y hormigones de escorias activadas alcalinamente, obtenidos cuando el activador es un silicato sódico, desarrollan unas retracciones al secado hasta cuatro veces superiores a los correspondientes de cemento Portland. Esta desventaja tecnológica afecta mucho a sus posibilidades de aplicación.

En trabajos previos $(13,7)$ se ha comprobado que la incorporación de fibras acrílicas (en un porcentaje de hasta un $1 \%$ en peso de ligante) no reduce dicha retracción, mientras que las de polipropileno lo reducían en un $25 \%$. En el presente trabajo, el objetivo ha sido estudiar

\section{INTRODUCTION}

Portland cement manufacture is an energy-intensive process (calling for nearly 7,000 Mj/t of cement) with a high Green House Gases (GHG) emission rate (approximately one tonne of $\mathrm{CO}_{2}$ per tonne of cement). The need to ensure the sustainability of Portland cement manufacture entails the pursuit of improved processes (implementation of better technologies and re-use of waste as partial substitutes for fuels and prime materials) and the development of new energy-efficient binders with low pollution levels. These include so-called "alkaline cements and concretes" obtained by thoroughly mixing a very alkaline solution with natural (clay) or artificial (blast furnace slag or aluminosilicate fly ash) materials. The characteristics and properties of these cements vary widely depending on the starting material.

When vitreous blast furnace slag is used, the product is an alkali-activated slag cement. Although first developed by V. D. Glukhoswskii (1-2) in the nineteen sixties, such cements did not begin to attract the interest of the international scientific community until the nineties.

Alkali-activated slag cements and concretes are characterized by strength comparable to those of Portland cement, with compressive strength values of up to 3040 MPa after 24 hours. Different authors have tested these cements and concretes for resistance to sulphate and sea water attack (3-4), chloride diffusion (3-4), acid media (6), freeze-thaw cycles (7-8), high temperatures (9) and so on. Their optimal durability is associated with the nature of their hydration products (1011) and low porosity and permeability (12). However, alkali-activated slag cements and concretes obtained with sodium silicate activators exhibit drying shrinkage rates up to four times greater than in Portland cement. This drawback has a clear impact on their applicability.

Previous studies $(13,7)$ showed that while such shrinkage is not reduced by the inclusion of acrylic fibres (up to $1 \%$ by weight of binder), it is $25 \%$ less acute when polypropylene fibres are added. The purpose of the present study was to analyze the effect on alkali-activated slag 
el efecto de fibras de vidrio alcali-resistente (AR) especialmente diseñadas para reducir la retracción al secado en sistemas cementantes, en morteros de escorias activadas alcalinamente.

\section{PARTE EXPERIMENTAL}

\subsection{Materiales utilizados y preparación de morteros}

En el presente trabajo se ha utilizado una escoria de horno alto y un cemento Portland tipo I 52.5 R, cuya composición química se muestra en la Tabla 1 . La superficie específica de la escoria y del cemento Portland eran de 325 y $360 \mathrm{~m}^{2} / \mathrm{kg}$, respectivamente, y el contenido en fase vítrea de la escoria de horno alto era del $99 \%$. La escoria de horno alto se activó alcalinamente con una disolución de waterglass $\left(\mathrm{Na}_{2} \mathrm{O} \cdot \mathrm{nSiO}_{2} \cdot \mathrm{mH}_{2} \mathrm{O}+\mathrm{NaOH}\right)$ que contenía un $4 \%$ de $\mathrm{Na}_{2} \mathrm{O}$, con respecto a la masa de escoria y una relación $\mathrm{SiO}_{2} / \mathrm{Na}_{2} \mathrm{O}$ de 1,18 .

Se prepararon morteros de escoria activada alcalinamente (AAS) y de cemento Portland (OPC) con una relación árido/escoria $=1 / 3$. La relación líquido/sólido varió dependiendo del tipo de ligante, en los morteros de OPC esa relación fue de 0,50 y en los de AAS de 0,56. Se incorporó la fibra de vidrio en un porcentaje entre el 0 y el $1,1 \%$ en peso de ligante. Las fibras tenían un diámetro comprendido entre 14 y $20 \mu \mathrm{m}$ y una longitud de $12 \mathrm{~mm}$.

\subsection{Ensayos realizados}

Los morteros preparados fueron sometidos a los siguientes ensayos:

\subsubsection{Retracción al secado}

Se determinó la retracción al secado, de acuerdo a la norma UNE 80-112-89, en probetas de mortero prismáticas de $2,5 \times 2,5 \times 28,7 \mathrm{~cm}$ de escoria activada alcalinamente y cemento Portland. El contenido de fibra en los morteros varió entre $0-1,1 \%$ en peso de ligante. Este ensayo se realizó sobre probetas curadas al $50 \%$ de humedad relativa. mortars of alkali-resistant (AR) glassfibre especially designed to reduce drying shrinkage in cementitious systems.

\section{EXPERIMENTAL}

\subsection{Materials used and preparation of mortars}

The chemical compositions of the blast furnace slag and CEM I 52.5R Portland cement used in this study are given in Table 1. The specific surface for the slag and the Portland cement were 325 and $360 \mathrm{~m}^{2} / \mathrm{kg}$, respectively; the vitreous phase content of the slag was 99\%. The slag was activated with a waterglass solution $\left(\mathrm{Na}_{2} \mathrm{O} \cdot \mathrm{nSiO} \mathrm{S}_{2} \cdot \mathrm{mH}_{2} \mathrm{O}+\mathrm{H}_{2} \mathrm{O}\right)$ containing $4 \% \mathrm{Na}_{2} \mathrm{O}$ by slag mass and a $\mathrm{SiO}_{2} / \mathrm{Na}_{2} \mathrm{O}$ ratio of 1.18 .

Alkali-activated slag (AAS) and Portland cement (OPC) mortars were prepared with an aggregate/slag ratio of $3 / 1$. The liquid/solid ratio for the OPC mortars was 0.50 and for the AAS mortars 0.56. The percentage of $A R$ fibre added ranged from 0 to $1.1 \%$ by weight of the binder. The fibres used were 14-20 $\mu \mathrm{m}$ in diameter and $12 \mathrm{~mm}$ long.

\subsection{Tests conducted}

The mortars prepared were subjected to the following tests:

\subsubsection{Drying shrinkage}

Drying shrinkage was determined on alkali-activated slag and Portland cement mortar specimens measuring $2.5 x$ $2.5 \times 28.7 \mathrm{~cm}$ according to spanish standard UNE 80-11289. The fibre content in the mortars ranged from 0 to $1.1 \%$ by weight of the binder. This test was conducted on specimens cured at $50 \%$ relative humidity.

Tabla 1 / Table 1

Análisis químico de la escoria de horno alto y de cemento Portland Chemical analysis of blast furnace slag and Portland cement

\begin{tabular}{|c|c|c|c|c|c|c|c|c|c|c|}
\hline & $\mathrm{CaO}$ & $\mathrm{SiO}_{2}$ & $\mathrm{Al}_{2} \mathrm{O}_{3}$ & MgO & $\mathrm{Fe}_{2} \mathrm{O}_{3}$ & $\mathrm{SO}_{3}^{-}$ & $\mathbf{S}_{\mathbf{2}}^{-}$ & $\mathrm{Na}_{2} \mathrm{O}$ & P. F.*/L. I. & R. I.**/I. R. \\
\hline Escoria / Slag & 41.00 & 35.34 & 13.65 & 4.11 & 0.39 & 0.06 & 1.91 & 0.01 & 2.72 & 0.64 \\
\hline Cemento/Cement & 61.51 & 19.76 & 3.66 & 2.07 & 4.73 & 3.03 & - & 0.12 & 2.52 & 0.66 \\
\hline
\end{tabular}

* P. F. Pérdida al fuego/L. I. = Loss on ignition.

** R. I. Residuo insoluble/I. $R$. Insoluble residue. 
2.2.2. Resistencias mecánicas a compresión y flexotracción

Se determinaron las resistencias mecánicas a 2,7 y 28 días en probetas de mortero de $4 \times 4 \times 16 \mathrm{~cm}$ curadas al $99 \%$ de humedad relativa y $20 \pm 2{ }^{\circ} \mathrm{C}$, de acuerdo a la norma UNE-EN 196-1. El contenido de fibra en los morteros varió entre $0-1,1 \%$ en peso de ligante.

\subsubsection{Tenacidad y resistencia al impacto}

Este ensayo se realizó sobre morteros de cemento Portland y de escoria activada sin fibra y sobre otros que tenían incorporado un $0,22 \%$ de fibra AR. Se prepararon series de tres probetas prismáticas de cada mortero de $4 \times 4 \times 16 \mathrm{~cm}$. La determinación de la tenacidad se realizó a flexotracción sobre las probetas previamente curadas durante 28 días en cámara de humedad ( $\mathrm{T}^{\mathrm{a}}=21 \pm 2{ }^{\circ} \mathrm{C}$ y $\left.\mathrm{HR}>97 \%\right)$. Se empleó una máquina universal de ensayo Instrom 5582. El ensayo de realizó siguiendo la norma UNE 83-510, registrándose el diagrama carga-flecha, con el fin de determinar la tenacidad. La velocidad de deformación fue constante en 0,20 mm/min.

Para los ensayos de impacto se prepararon probetas de mortero de $16 \times 14 \times 2,5 \mathrm{~cm}$. El impacto se realizó mediante una esfera metálica de $540 \mathrm{~g}$, mantenida por un electroimán a una altura de 100 y $50 \mathrm{~cm}$ de la cara superior de la probeta. Con este sistema se determina la cantidad de energía de impactos precisa para producir la primera fisura y rotura total de las piezas. Los ensayos se realizaron a los 28 días de curado. El contenido de fibra AR en los morteros fue del $0,22 \%$, también se valoró la resistencia en morteros carente de fibra.

\subsubsection{Examen microscópico}

Se realizó un examen de los materiales a través de microscopía electrónica de barrido (SEM) y análisis por energías dispersivas (EDX). Este análisis se llevó a cabo sobre las probetas previamente ensayadas a impacto.

\subsubsection{Comportamiento frente a altas temperaturas}

Se prepararon probetas cúbicas de mortero de $4 \mathrm{~cm}$ de lado, de acuerdo a la norma UNE-EN 196-1, de los morteros de escoria activada con waterglass y de cemento con y sin incorporación de $0,22 \%$ de fibra de vidrio, con respecto al peso de ligante. Las probetas se conservaron en una cámara de humedad relativa del $99 \%$ y $20 \pm 2{ }^{\circ} \mathrm{C}$, durante 28 días. Posteriormente las probetas se sometieron durante 2 horas a temperaturas comprendidas entre $100^{\circ} \mathrm{C}$ y $1.200^{\circ} \mathrm{C}$. Se evaluó el efecto de la temperatura sobre sus resistencias mecánicas y la variación de peso. También se realizó un estudio de caracterización mineralógica por Difracción de Rayos X (DRX) sobre algunos de los morteros tratados térmicamente.

\subsubsection{Mechanical (compressive and flexural) strengths}

Mechanical strength was determined at 2, 7 and 28 days on $4 \times 4 \times 16-\mathrm{cm}$ mortar specimens cured at $99 \%$ relative humidity and a temperature of $20 \pm 2{ }^{\circ} \mathrm{C}$, in accordance with Spanish standard UNE-EN 196-1. The fibre content in the mortars ranged from 0 to $1.1 \%$ by weight of the binder.

\subsubsection{Toughness and impact resistance}

The toughness test was conducted on Portland cement and activated slag mortars with 0 and $0.22 \%$ AR fibre. Series of three $4 \times 4 \times 16-\mathrm{cm}$ prisms were prepared from each type of mortar. Flexural toughness was determined on specimens cured for 28 days in a humid chamher $\left(T=21 \pm 2{ }^{\circ} \mathrm{C}\right.$ and $\left.\mathrm{RH}>97 \%\right)$. An Instrom 5582 universal testing machine was used, following the protocol laid down in Spanish standard UNE 83-510, and the load-deflection diagram was recorded to determine toughness. The deformation rate was a constant $0.20 \mathrm{~mm} / \mathrm{min}$.

Specimens measuring $16 \times 14 \times 2.5 \mathrm{~cm}$ were prepared for the impact test, in which a 540-g metallic sphere was released from an electromagnet and dropped on to the specimen from heights of 100 and $50 \mathrm{~cm}$. This arrangement suffices to determine the amount of impact energy required to generate the first crack in and total rupture of the sample. Tests were conducted after curing the specimens for 28 days. Both plain mortars and mortars with a $0.22 \%$ AR fibre content were tested.

\subsubsection{Microscopical study}

The materials were studied with scanning electron microscopy (SEM) and energy dispersive X-ray (EDX) techniques. These analyses were performed on the impact test specimens, after the trials.

\subsubsection{Behaviour to high temperatures}

Cubic ( $4 \times 4 \times 4-\mathrm{cm})$ specimens were prepared as specified in Spanish standard UNE-EN 196-1 with waterglass-activated slag and cement mortars, with and without $0.22 \%$ glassfibre (by weight of binder). The samples were stored for 28 days in a humid chamher at a relative humidity was $99 \%$ and a temperature of $20 \pm 2{ }^{\circ} \mathrm{C}$. The specimens were subsequently subjected to temperatures ranging from 100 to $1,200{ }^{\circ} \mathrm{C}$ for two hours to evaluate the effect of temperature on mechanical strength and specimen weight. $X$-ray diffraction mineralogical characterization was performed on some of the thermally treated specimens. 


\section{RESULTADOS Y DISCUSIÓN}

\subsection{Retracción al secado}

En la Figura 1 se muestra el porcentaje de retracción que experimentan los morteros, en el tiempo, tras permanecer en unas condiciones de $21 \pm 2{ }^{\circ} \mathrm{C}$ y una humedad relativa (HR) ambiente del $50 \%$. En estas condiciones de baja HR, se evalúa la estabilidad dimensional de las probetas por retracción al secado. Como se puede observar en la Figura 1, la retracción de las probetas de cemento Portland (OPC) es siempre inferior al $0,1 \%$, y las fibras de vidrio no inducen unas mejoras significativas en la reducción de dicha retracción, únicamente cuando el contenido de fibra en el mortero es del $0,11 \%$, se observa una disminución de dicha retracción, en valores del orden de un $8 \%$.

Sin embargo, en los morteros de escoria activada (AAS), la retracción al secado se sitúa en el entorno del 0,4\%, siendo, por tanto, hasta 4 veces superior a la de los morteros de OPC. La incorporación de fibras de vidrio a estos morteros de AAS reduce esa retracción cuando el contenido en fibra es del $0,22 \%$. Esta reducción se estima alrededor del $20 \%$, siendo del mismo orden a la inducida por las fibras de polipropileno (7) (en un contenido de un $1 \%$ en peso escoria) en este mismo tipo de morteros. La retracción final de estos morteros sigue siendo superior a la de los cementos Portland, aunque su reducción en un $20 \%$ es un resultado claramente positivo.

Contenidos más elevados de fibra AR no parecen mejorar la retracción. Una posible explicación a este comportamiento

\section{RESULTS AND DISCUSSION}

\subsection{Drying shrinkage}

Figure 1 shows mortar drying shrinkage, in per cent, versus curing time under low (50\%) relative humidity $(\mathrm{RH})$ and a temperature of $21 \pm 2{ }^{\circ} \mathrm{C}$. In these low $\mathrm{RH}$ conditions, the dimensional stability of specimens is evaluated. Drying shrinkage in Portland cement (OPC) specimens, always under $0.1 \%$, was not significantly affected by the inclusion of glassfibre and was only observed to decrease, by values on the order of $8 \%$, when fibre was included at a close of $0.11 \%$.

Drying shrinkage in alkali-activated slag (AAS) mortars, on the contrary, was around of $0.4 \%$, four times higher than in OPC mortars. The inclusion of glassfibre at a close of $0.22 \%$ reduced shrinkage in these AAS mortars by around $20 \%$, a decrease on the same order as induced by polypropylene fibres (7) (inclusion at $1 \%$ by weight of slag) in such mortars. While final shrinkage in these mortars continued to be higher than recorded for Portland cement, this $20 \%$ reduction is an obvious improvement.

A higher AR fibre content did not appear to prevent shrinkage any more effectively. One possible explanation

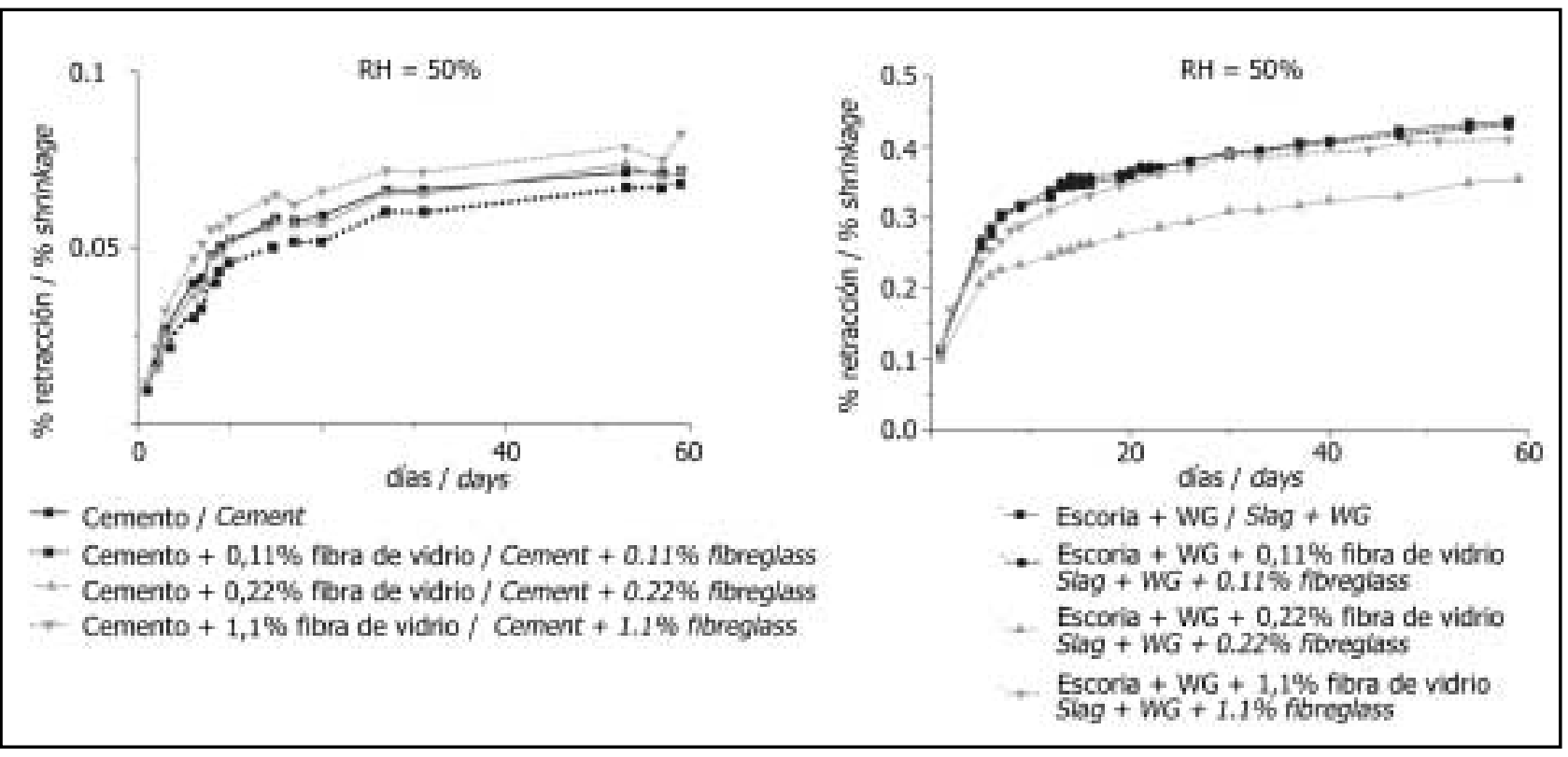

Figura 1. Retracción al secado de los morteros de OPC y AAS. Efecto de las fibras AR. Figure 1. Drying shrinkage in OPC and AAS mortars. Effect of AR fibre. 
se puede encontrar en la falta de homogeneidad de las probetas que incorporan altos contenidos de fibra (14).

\subsection{Resistencias mecánicas a compresión y flexotracción}

En las Figuras 2 y 3 se puede observar el comportamiento resistente de los morteros de OPC y AAS reforzados con fibra de vidrio $A R$, respectivamente. Del análisis de dichas gráficas se deduce que, a partir de los 7 días de curado, las resistencias mecánicas a flexotracción y compresión de los morteros de AAS son superiores a las desarrolladas en los morteros de OPC.

La incorporación de fibras AR induce ligeros cambios en el comportamiento resistente. Como era de esperar, en los morteros de OPC se produce un incremento en la resistencia a flexotracción, según aumenta el contenido de fibra en los mismos, no viéndose afectado el comportamiento a compresión. En los morteros de AAS, al igual que en los de OPC, las fibras de AR hasta un contenido del 0,22\%, inducen una mejora en las resistencias a flexotracción, no alterando los valores resistentes a compresión.

\subsection{Tenacidad y resistencia al impacto}

Se define tenacidad como el área limitada por la curva carga-flecha desde el origen 0 corregido del eje de abcisas y la ordenada correspondiente a una flecha de 1/150 de la luz entre ejes de apoyo, es decir, 0,933 mm. En la Tabla 2 se muestran los valores de tenacidad obtenidos en las probetas estudiadas. De las gráficas carga-deformación se deduce que al producirse la primera fisura la probeta rompe, indicando que la fibra no actúa como elemento de unión en la matriz. Ello se debe probablemente a su baja dosificación en los morteros. for this finding may be the lack of homogeneity in specimens with a high fibre content (14).

\subsection{Mechanical comprensive and flexural strengths}

Glassfibre-reinforced OPC and AAS mortar strength patterns are given in Figures 2 and 3, respectively. An analysis of these graphs shows that after 7 days of curing, the AAS specimens had greater flexural and compressive strength than the OPC mortars.

The inclusion of AR fibres induced slight changes in strength performance. As would be expected, in OPC mortars flexural strength rose with the fibre content, while compressive strength was unaffected. The addition of $A R$ fibres at dosage of up to $0.22 \%$ in AAS prisms led, as in the OPC specimens, to enhanced flexural strength but did not alter the compressive strength values.

\subsection{Toughness and impact resistance}

Toughness is defined to be the area on the load-deflection curve delimited by the corrected $x$-axis origin and the $y$-axis value corresponding to a deflection of $1 / 50$ of the span between supports, i.e. $0.933 \mathrm{~mm}$. Table 2 gives the toughness values obtained for the specimens studied. The deduction drawn from the load-deformation curves, namely that the specimens break with the first crack, is an indication that the fibre does not enhance matrix amalgamation. This may be attributed to the low dosage used in the mortars.

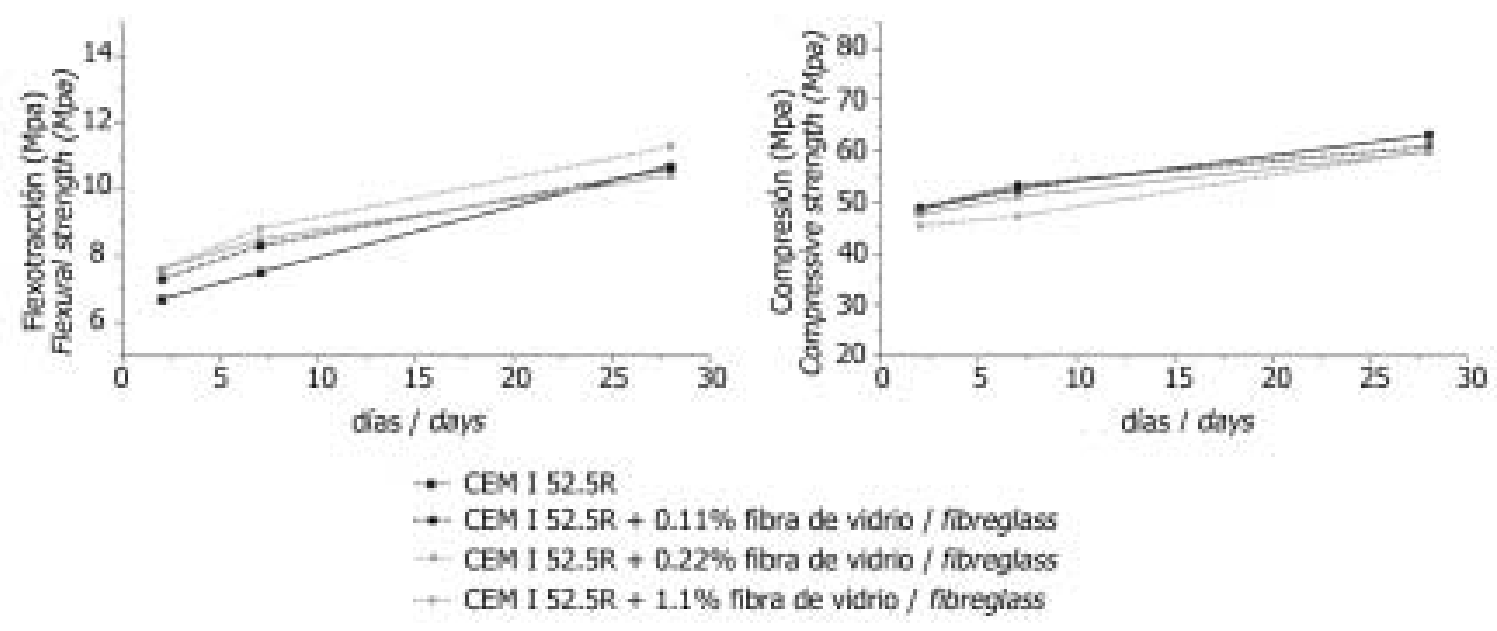

Figura 2. Comportamiento resistente de los morteros de OPC reforzados con fibras AR. Figure 2. Strength in AR fibre-reinforced OPC mortars. 


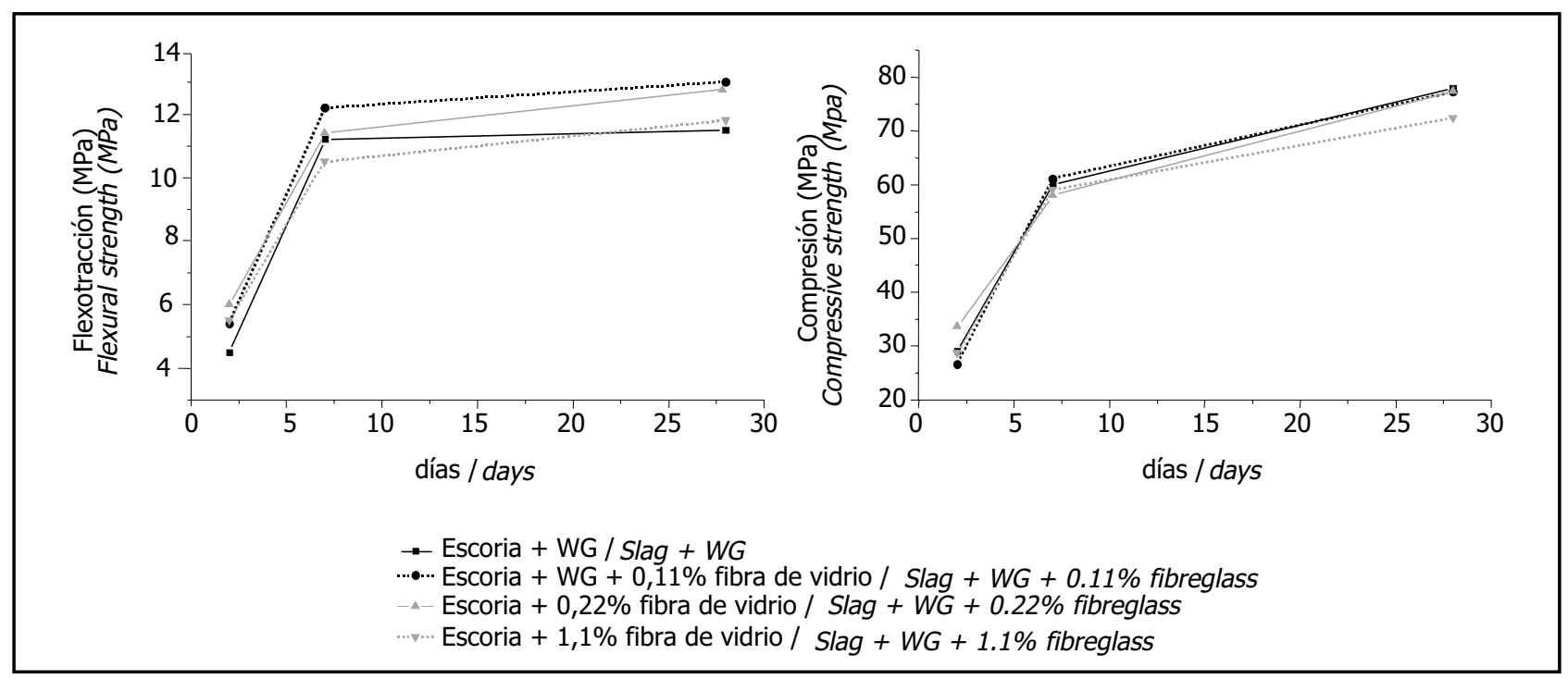

Figura 3. Comportamiento resistente de los morteros de AAS reforzados con fibras AR.

Figure 3. Strength in AR fibre-reinforced AAS mortars.

Los resultados obtenidos tras los ensayos a impacto, realizados a diferentes distancias (esfera de $540 \mathrm{~g}$ a 100 y 50 $\mathrm{cm}$ ) y con diferentes bases soporte (arena y losa cerámica) han sido los mismos. En todos los morteros, ya sean de OPC o AAS, con $(0,22 \%)$ y sin fibra se fisuran y rompen al primer impacto. Las fibras no inducen, en los materiales estudiados, mejoras en su resistencia al impacto.

\subsection{Examen microscópico}

En las Figuras 4 y 5 se muestran imágenes de SEM de los morteros de OPC y ASS, respectivamente. En dichas imágenes se puede observar que la adherencia de la fibra a la matriz no es excesivamente buena. También se observa la huella dejada por una fibra. Dentro de esta huella predominan los cristales de portlandita. Hay que recordar que este estudio se realizó sobre morteros previamente ensayados a impacto. Hay que destacar que la superficie de la fibra no se encuentra alterada ni con depósitos externo. Resultados similares han sido encontrados por otros autores (15).

Por el contrario, en los morteros de AAS reforzados se han encontrado algunas fibras con un claro ataque superficial, tal y como puede observarse en las imágenes
The impact tests conducted at different distances (540-g sphere dropped from 100 and $50 \mathrm{~cm}$ ) and on different supports (sand and ceramic tile) yielded the same results for all the OPC and AAS mortars, with (0.22\%) or without fibres, which cracked and broke after the first impact. The inclusion of glassfibre failed to improve impact resistance in any of the materials studied.

\subsection{Microscopic study}

As the SEM images of the OPC and AAS mortars depicted in Figures 4 and 5 show, the fibres did not bond particularly well to the matrix respectivety. In the gap left by one of the fibres, also visible in these images, there is a predominance of portlandite crystals. It will be recalled that this study was conducted on mortars previously subjected to impact testing. The surface of these fibres is unaltered and free of any external deposits. Similar results have been reported by other authors (15).

In AAS mortars, on the contrary, some fibre surfaces show clear signs of attack, such as in the images in Figure 5. This may be due to the higher $\mathrm{pH}$ in the aqueous phase

Tabla 2 / Table 2

Resistencia a la Tenacidad de los morteros

Mortar toughness

\begin{tabular}{|c|c|c|c|c|}
\hline Tipo mortero / Mortar type & OPC & OPC & AAS & AAS \\
\hline \% fibra AR / \% AR fibre & $0 \%$ & $0.22 \%$ & $0 \%$ & $0.22 \%$ \\
\hline Tenacidad (J) / Toughness (J) & $0.143 \pm 0.025$ & $0.154 \pm 0.031$ & $0.214 \pm 0.039$ & $0.172 \pm 0.009$ \\
\hline
\end{tabular}




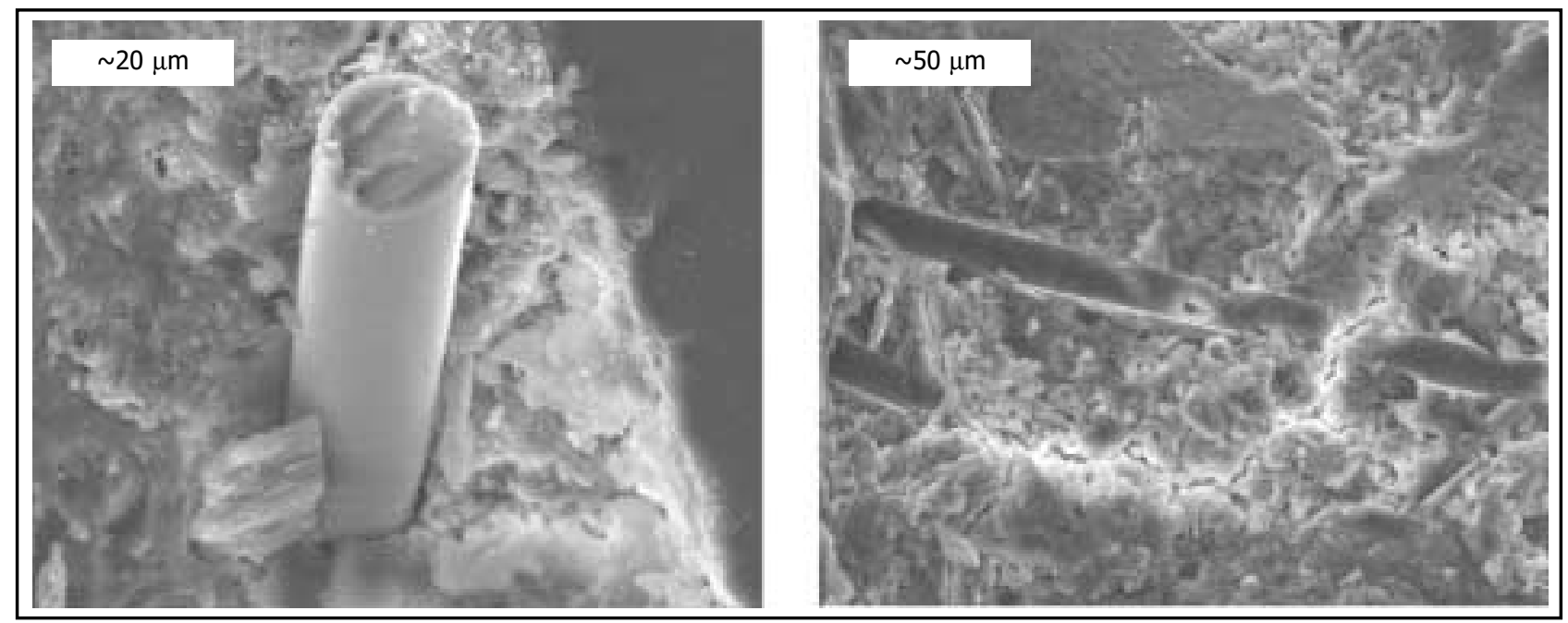

Figura 4. Imágenes de SEM de los morteros de OPC reforzados con fibras AR. Figure 4. SEM images of AR fibre-reinforced OPC mortars.

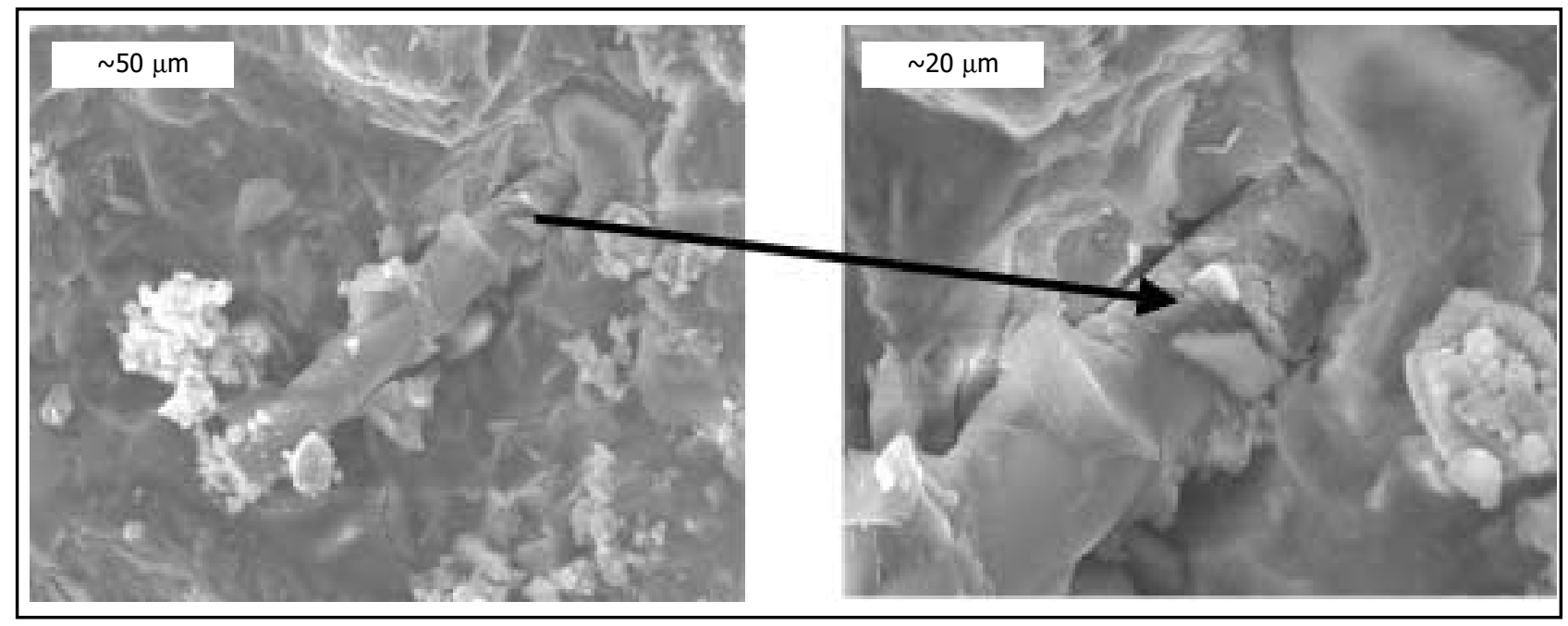

Figura 5. Imágenes de SEM de los morteros de AAS reforzados con fibra.

Figure 5. SEM images of AR fibre-reinforced AAS mortars.

de la Figura 5. Ello se puede deber al mayor $\mathrm{pH}$ de la fase acuosa de estas pastas, con respecto a las de cemento Portland (16). En el mismo mortero se han encontrado otras fibras con depósitos externos y sin ataque superficial.

\subsection{Comportamiento frente a altas temperaturas}

En la Figura 6 se representa la resistencia residual de los morteros tras su ensayo a las diferentes temperaturas. Se observa que las resistencias mecánicas residuales de los morteros AAS a los $500{ }^{\circ} \mathrm{C}$ son superiores, hasta en un $50 \%$, a las de OPC. Resultados similares fueron obtenidos por otros autores (9). Esto puede ser debido a que en torno a $500{ }^{\circ} \mathrm{C}$ se produce, en las pastas de OPC, la deshidratación de la $\mathrm{Ca}(\mathrm{OH})_{2}$ o portlandita, con la consiguiente of these than in the Portland cement mortars (16). Other fibres with external deposits but no signs of surface attack were found in the same mortar.

\subsection{Behaviour to high temperatures}

Figure 6 shows the residual strength in the mortars after testing at different temperatures. AAS mortars were found to have up to $50 \%$ higher residual strength than OPC mortars after treatment at $500^{\circ} \mathrm{C}$. Other authors have reported similar results (9). This may be due to the fact that $\mathrm{CA}(\mathrm{OH})_{2}$ (portlandite) dehydrates at around $500{ }^{\circ} \mathrm{C}$ in OPC pastes, with the concomitant loss of volume (around 44\%) (17) and micro-cracking. Although 
contracción de volumen (alrededor de un 44\%) (17) y formación de microfisuras. Los morteros de AAS carecen de portlandita. Sin embargo, sí se observa que en este rango de temperaturas $\left(25-500^{\circ} \mathrm{C}\right)$, los morteros de AAS experimentan una mayor pérdida de peso (ver Figura 7) que los morteros de OPC: ello se puede explicar por la diferente estructura y composición de los geles CSH presentes en ambas pastas. Los geles CSH formados en las pastas de AAS activadas con waterglass tienen una baja relación $\mathrm{Ca} / \mathrm{Si}$ y un mayor contenido en agua interlaminar, cuya eliminación induce la elevada retracción de estos morteros (18). Esa mayor pérdida de peso se debe a la eliminación de dicho agua interlaminar. La presencia de fibra de AR mejora la resistencia residual del mortero de OPC hasta $500{ }^{\circ} \mathrm{C}$; sin embargo, no afecta, ni positiva ni negativamente, a los morteros de AAS. La incorporación de fibra de vidrio a los morteros de OPC disminuye la expansión térmica que experimentan como consecuencia de la descomposición de los compuestos hidratados (portlandita y gel CSH) e incrementa la cohesión (19).

Entre 500 y $700^{\circ} \mathrm{C}$, la pérdida de resistencia en los morteros de AAS es más marcada que en los morteros de OPC. Ello se debe a que a dichas temperaturas se produce la descomposición total del gel CSH. A parte de la diferente estructura y composición del gel $\mathrm{CSH}$ en las pastas de AAS, esta fase también se encuentra en mayor proporción que en los morteros de OPC. En este rango de temperaturas las fibras de AR no modifican sustancialmente el comportamiento resistente.

Los resultados obtenidos a partir de $1.000{ }^{\circ} \mathrm{C}$ muestran que las resistencias mecánicas de los morteros de AAS se recuperan, a diferencia de lo que ocurre con los de OPC.

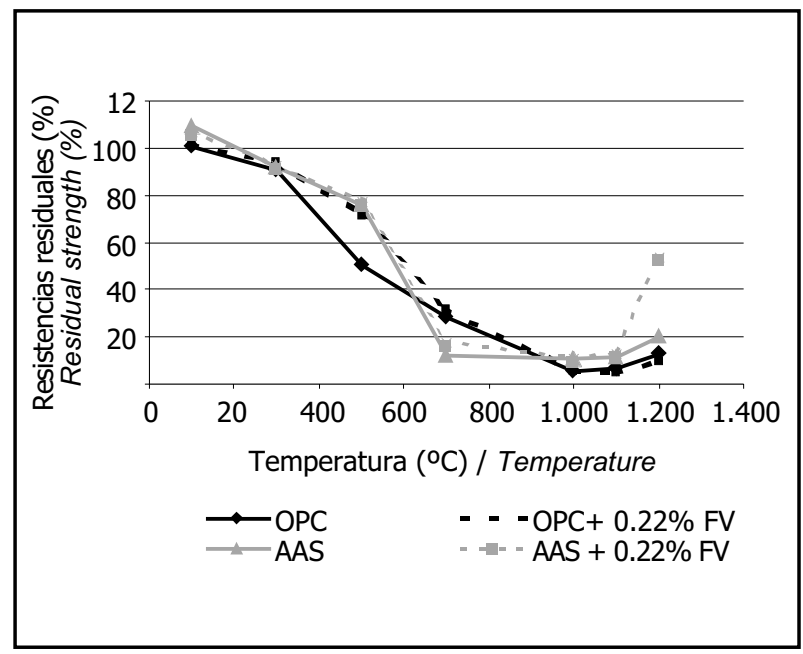

Figura 6. Resistencias residuales de los morteros tras el tratamiento térmico entre $100-1.200^{\circ} \mathrm{C}$.

Figure 6. Residual strength in mortars after thermal treatment at $100-1,200{ }^{\circ} \mathrm{C}$
AAS mortars have no portlandite, they exhibited a greater weight loss in this temperature range (25-500 ${ }^{\circ} \mathrm{C}$ ) than the OPC mortars (see Figure 7). This may be explained by the differences in structure and composition of the $\mathrm{CSH}$ gels present in the two pastes. The $\mathrm{CSH}$ gels formed in waterglass-activated slag pastes have a low $\mathrm{Ca} / \mathrm{Si}$ ratio and higher interlaminar water content; the elimination of this water is responsible for the substantial shrinkage observed in these mortars (18). The greater weight loss is also due to the elimination of such interstitial water. The presence of $A R$ fibre improves the residual strength of OPC mortars up to $500^{\circ} \mathrm{C}$; but it has no effect, adverse or beneficial, on AAS mortars in this regard. The inclusion of glassfibre in OPC mortars lowers thermal expansion due to the decomposition of hydrated compounds (portlandite and CSH gel) and enhances bonding (19).

In the 500-700 ${ }^{\circ} \mathrm{C}$ range, strength loss was much more acute in AAS than OPC mortars because the CSH gel decomposes entirely at such temperatures. In addition to the different structure and composition of the $\mathrm{CSH}$ gel in $A A S$ pastes, the proportion of this phase is greater in these than in OPC mortars. AR fibres had no substantial effect on resistance in this temperature range.

The results obtained at $1,000{ }^{\circ} \mathrm{C}$ and over showed that while AAS mortars recovered their mechanical strength, the OPC mortars did not. Rovnanki (20) et al. reported

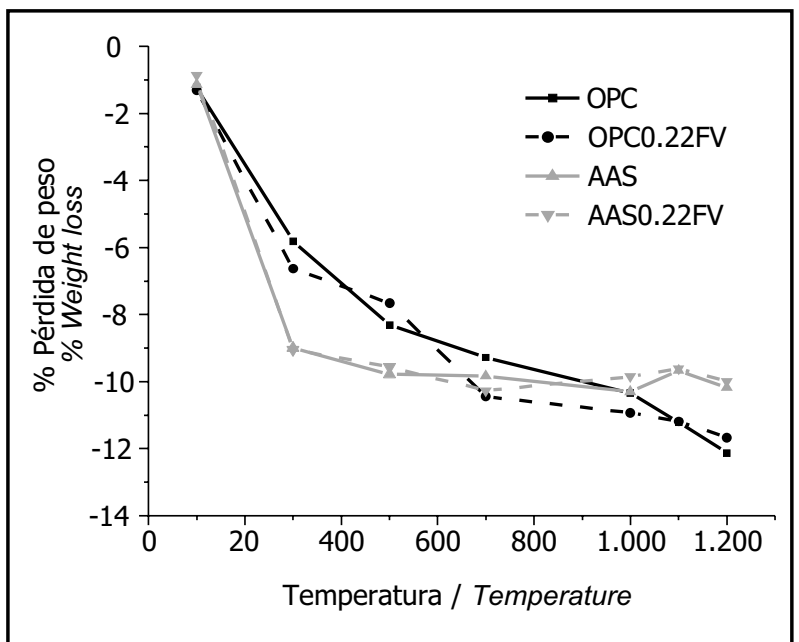

Figura 7. Pérdida de peso de los morteros tras el tratamiento térmico entre $100-1.200^{\circ} \mathrm{C}$.

Figure 7. Weight loss in mortars after thermal treatment at $100-1,200^{\circ} \mathrm{C}$ 
Rovnanik et al. (20) también observaron algo parecido, aunque no explicaron las causas de ese incremento de resistencias. En ausencia de fibra de vidrio $A R$, los morteros ensayados a $1.200{ }^{\circ} \mathrm{C}$ recuperan hasta un $20 \%$ sus resistencias mecánicas residuales y con la incorporación de $0,22 \%$ de fibra $A R$, esa recuperación llega a ser hasta del $54 \%$. Las razones de este incremento pueden ser debidas, por una parte, a la fusión parcial de la fibra y, por otra, a la fusión de la escoria anhidra (18), rellenando ambos fundidos los poros. Las fibras son incombustibles y su punto de ablandamiento se sitúa en $860^{\circ} \mathrm{C}$. El estudio realizado por DRX sobre las muestras de AAS (enriquecidas en ligante) y tratadas a $1.200^{\circ} \mathrm{C}$, con y sin fibra de vidrio, confirman que se ha producido la fusión de la escoria anhidra. Como se puede observar en los difractogramas (ver Figura 8), se identifican las fases gelenita y akermanita, procedentes ambas de la recristalización de la escoria y en forma minoritaria se identifica también una fase tipo nephelina. No se observan diferencias mineralógicas entre las muestras, indicando que el efecto positivo de la fibra es debido, probablemente, a su fusión parcial. A temperaturas superiores a $1.200{ }^{\circ} \mathrm{C}$ se produce una pérdida total de la cohesión del mortero por la fusión total de la escoria y la fibra. similar findings, although they did not explain the reason for such an increase. In the absence of $A R$ fibre, the mortars tested at 1,200 ${ }^{\circ} \mathrm{C}$ recovered residual mechanical strength at a rate of up to $20 \%$, and when fibre was included, recovery climbed to up to $54 \%$. The reasons for this increase may be due, on the one hand, to the partial fusion of the fibre, and on the other to the fusion of the anhydrous slag (18), both of which would then fill the pores in the material. The softening point of the fibres, which are incombustible, is $860^{\circ} \mathrm{C}$. An XRD study of the (binder-enriched) AAS samples treated at 1,200 ${ }^{\circ} \mathrm{C}$, with and without glassfibre, confirmed the fusion of the anhydrous slag. The gelenite and akermanite phases identified in the diffractograms (Figure 8) are the result of slag recrystallization. A nepheline-type minority phase was also detected. The absence of mineralogical differences between the samples would indicate that the beneficial effect of the fibre is very likely due to its partial fusion. At temperatures of over 1,200 ${ }^{\circ} \mathrm{C}$, mortar bonding disintegrated entirely due to the total fusion of slag and fibre.

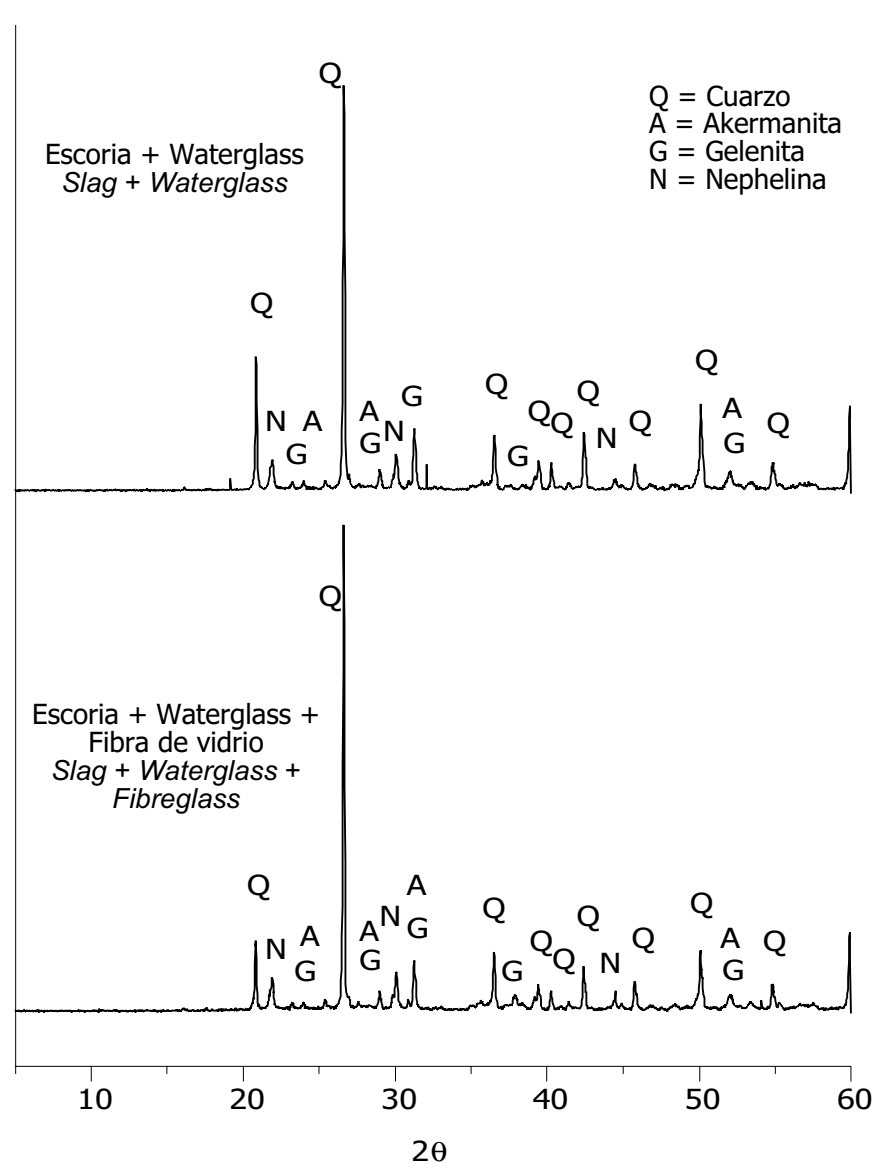

Figura 8. Difractogramas de morteros de escoria activada con waterglass con y sin fibra de vidrio después de exponerse a $1.200{ }^{\circ} \mathrm{C}$. Figure 8. Diffractograms of waterglass-activated slag mortar with and without glassfibre, after exposure to temperatures of $1,200{ }^{\circ} \mathrm{C}$. 


\section{CONCLUSIONES}

Del estudio realizado se pueden extraer las siguientes conclusiones:

1. La incorporación de fibras de vidrio $A R$, en un contenido en torno al $0,22 \%$ en peso de ligante, en morteros de escoria activada alcalinamente con waterglass reduce la retracción al secado en un $20 \%$.

2. Este porcentaje de fibra en el mortero no afecta negativamente al desarrollo resistente a flexotracción y compresión. Tampoco afecta a su resistencia al impacto $y$ tenacidad.

3. El estudio microscópico ha revelado que algunas fibras de vidrio AR experimetan un ataque superficial en los sistemas de escoria activada alcalinamente.

4. El comportamiento frente a altas temperaturas de los morteros de AAS y OPC es diferente debido, fundamentalmente, a la distinta composición mineralógica y las diferencias en la estructura y composición de sus geles CSH. A temperatuas superiores a $1.000{ }^{\circ} \mathrm{C}$, los morteros de AAS recuperan sus resistencias mecánicas. En ausencia de fibra de vidrio esa recuperación es del $20 \%$, y con fibra AR se recupera más del $50 \%$ de las resistencias iniciales. Ello se debe a la fusión de la escoria anhidra y de la fibra, rellenando ambos fundidos los poros del mortero.

\section{AGRADECIMIENTOS}

Los autores quieren expresar su agradecimiento al MEC por la concesión del proyecto MAT2001-1490, con cuya financiación se ha realizado este trabajo. M. Palacios agradece también a la CAM la concesión de una beca predoctoral, en cuyo marco se ha realizado este estudio. Los autores también agradecen a Vetrotrex el suministro de la fibra de vidrio AR.

\section{CONCLUSIONS}

The key conclusions to be drawn from the present study are as follows:

1. The inclusion of $A R$ glassfibre at a dosage of around $0.22 \%$ by weight of binder, reduces drying shrinkage in waterglass activated slag mortars by $20 \%$.

2. This percentage of fibre does not detract from mortar flexural or compressive strength, nor does it affect its toughness or impact resistance.

3. Microscopic studies reveal that the surfaces of some $A R$ fibres are attacked in alkali-activated slag systems.

4. The differences in AAS and OPC high temperature are primarily due to the differences in their mineralogical composition and the structure and composition of their $\mathrm{CSH}$ gels. At temperatures of over $1000^{\circ} \mathrm{C}$, plain AAS mortars recover $20 \%$, and AR fibre-reinforced slag cement mortars over $50 \%$, of their initial strength because the pores in the mortar are filled by the fused anhydrous slag and fibre.

\section{ACKNOWLEDGEMENTS}

This study was funded by the Spanish Ministry of Education and Science under project MAT2001-1490. M. Palacios participated in this project under a pre-PhD grant by Comunidad de Madrid. The authors wish to thank Vetrotrex for supplying the AR glassfibre used.

\section{BIBLIOGRAFÍA / BIBLIOGRAPHY}

(1) Glukhovskij, V., Zaitsev, Y. y Pakhomow, V.: "Slag-alkaline cements and concrete-structures, properties, technological and economical aspects of the use", Silicates Industriels, 10 (1983), pp. 197-200.

(2) Glukhovskij, V., Rostowkaja, G. S. y Rumyna, G. V.: "High strength slag-akali cement", VII ICCC (París) (1980), vol. III, V-164-168.

(3) Puertas, F., Gutierrez, R. De, Fernández-Jiménez, A., Delvasto, S. y Maldonado, J.: "Morteros de cementos alcalinos. Resistencia química al ataque por sulfatos y agua de mar", Mater. Construcc., vol. 52, n० 267 (2002), pp. 55-71.

(4) Byfors, K., Klingstedt, G., Lehtonen, V., Pyy, H. y Romben, L.: "Durability of concrete made with alkali-activated slag", 3rd Inter. Conf. on fly-ash, silica fume, slag and natural pozzolans in concrete (Norway) (1989), vol. 2, pp. 1429-1466.

(5) Deja, J. y Malolepszy, J.: "Resistance of alkali-activated slag mortars to chlorine solution", $3^{\text {rd }}$ Inter. Conf. on fly-ash, silica fume, slag and natural pozzolans in concrete (Norway) (1989), vol. 2, SP 114-75, pp. 1547-1563.

(6) Bakharev, T., Sanjayan, J. G. y Cheng, Y. B.: "Resistance of alkali-activated slag concrete to acid attack", Cem. Concr. Res., vol. 33 (2003), pp. 1607-1611.

(7) Puertas, F., Amat, T., Fernández-Jiménez, A. y Vázquez, T.: "Mechanical and durable behaviour of alkaline cement mortars reinforced with polypropylene fibres", Cem. Concr. Res., vol. 33 (2003), pp. 2031-2036.

(8) Krivenko, P. V.: "Alkaline cements and concretes: problems of durability", $2^{\text {nd }}$ Intern. Conf. Alkaline Cements and Concretes (Kiev) (1999), pp. 3-43. 
(9) Gutiérrez, R. De, Maldonado, J. y Gutiérrez, C.: "Resistencia a temperaturas elevadas de escorias activadas alcalinamente", Mater. Construcc., vol. 54, no 276 (2004).

(10) Fernández-Jiménez, A., Puertas, F., Sobrados, I. y Sanz, J.: "Structure of calcium silicate hydrates formed in alkaline-activated slag: Influence of the type of alkaline activator", J. Am. Ceram. Soc., 86 (8), (2003), pp. 1389-1394.

(11) Escalante-García, J. I., Fuentes, A. F., Gorokhovsky, A., Fraile-Luna, P. E. y Mendoza-Suárez, G.: "Hydration products and reactivity of blast-furnace slag activated by various alkalis", J. Am. Ceram. Soc., 86 (12), pp. 2148-2153.

(12) Collins, F. y Sanjayan, J. G.: "Effect of pore size distribution on drying shrinkage of alkali-activated slag concrete", Cem. Concr. Res., vol. 30 (2000), pp. 1401-1406.

(13) Puertas, F., Amat, T. y Vázquez, T.: "Comportamiento de morteros de cementos alcalinos reforzados con fibras acrílicas y de polipropileno", Mater. Construcc., vol. 50, no 259 (2000), pp. 69-84.

(14) Miravete, A., Mieres, J. M., Calvo, I., Comino, P., Chminilli, A., Cuartero, J. y Tolosa, N.: "Comportamiento de la fibra de vidrio AR para aplicaciones estructurales en la construcción", Mater. Construcc., vol. 55, no 280 (2005), pp. 63-69.

(15) Rincón, J. M., Romero, M., Hernández-Crespo, M., Talero, R. y García Santos, A.: "Microestructura de un material compuesto basdo en una matriz de cemento reforzado con fibras de polipropileno", Mater. Construcc., vol. 54, no 274 (2004), pp. 73-82.

(16) Puertas, F., Fernández-Jiménez, A. y Blanco-Varela, M. T.: "Pore solution in alkali-activated slag cement pastes. Relation to the composition and structure of calcium silicate hydrate", Cem. Concr. Res., vol. 34 (2004), pp. 139-148.

(17) Cülfik, M. S. y Özturan, T.: "Effect of elevated temperatures on the residual mechanical properties of high-performance morta", Cem. Concr. Res., 32 (2002), pp. 809-816.

(18) Palacios, M.: Empleo de aditivos orgánicos en la mejora de las propiedades de cementos y morteros de escoria activada alcalinamente. PhD. Tesis Doctoral. Universidad Autónoma de Madrid, 2006.

(19) Toman, J., Drchalova, J., Podebradska, J., Cerny, R. y Rovnanikova, P., "High temperature behavior of cement based composites", Proceedings of the International Conference on Building Physics, 2nd Antwerpen, Belgium, Edited by: Carmeliet, Hens, Vermeir, 2003, pp. 101-107.

(20) Rovnanik, P., Bayer, P. y Rovnanikova, P., "Properties of alkali-activated aluminosilicate composite after thermal treatment", $2^{\text {nd }}$ Non Traditional Cement and Concrete, Brno (Czech Republic), 2005, pp. 48-54. 